\title{
The role of receptivity in the courtship behavior of Podocnemis erythrocephala in captivity
}

\author{
Camila Rudge Ferrara • Larissa Schneider • \\ Richard C. Vogt $\cdot$ Joanna Burger
}

Received: 11 November 2008 /Revised: 16 June 2009 /Accepted: 30 August 2009 / Published online: 24 September 2009

(C) The Author(s) 2009. This article is published with open access at Springerlink.com

\begin{abstract}
The courtship behavior of Podocnemis erythrocephala (Red-headed Amazon River Turtle) in captivity was studied to examine female receptivity and male response to female rejection. We observed 20 females and 39 males in 150 sessions (3-6 h/day for a total of $450 \mathrm{~h}$ ). In $36 \%$ of the trials, there was no interaction between males and females, and $20 \%$ of the trials resulted in copulations. All males introduced into tanks approached females, and eventually there was aggression among the males. In $48 \%$ of the experiments, females also searched for or approached males. When males initially approached females, they either accepted the male's advances (14\%), rejected the male passively (38\%), or rejected the male aggressively (48\%). In $86 \%$ of the cases where males were rejected, $4 \%$ attempted to approach females again, and in $51 \%$ they were ultimately successful.
\end{abstract}

Keywords Courtship behavior · Podocnemididae .

Red-headed Amazon River turtle $\cdot$ Amazon

Courtship behavior is a fundamental aspect of the reproductive success of all individuals (Alcock 1993; Krebs and Davis 1993; Anderson 1994). There are several key component of courtship, including sexual advances, mate choice, and receptivity. In turtle species where females are larger than

C. R. Ferrara $(\triangle) \cdot$ L. Schneider $\cdot$ R. C. Vogt Coordenação de Biologia de Água Doce e Pesca Interior, Instituto Nacional de Pesquisas da Amazônia, Manaus, Amazonas, Brazil

e-mail: ferrara@terra.com.br

\section{J. Burger}

Division of Life Sciences, Rutgers University, 604 Allison Road,

Piscataway, NJ 08854-8082, USA males, males cannot force themselves on females, but instead must approach females and initiate courtship by displaying to the females (Berry and Shine 1980) Females, in response, can engage in courtship or reject the males. Following rejection, males can either persist or search for other females.

The early phases of approach and courtship are difficult to observe in nature, particularly for turtles that live in murky waters, or are widely distributed. In this paper, we use Podocnemis erythrocephala to examine female receptivity under laboratory conditions. Our main objectives were to determine female response to the approaches of males, the percentage of approaches that led to female involvement in courtship, the percentage that led to copulation, and whether females ever searched for males. We also describe briefly the sequence of behaviors patterns involved in courtship, mating, and those following initial rejection of the male by the female. We were also interested in the variations in courtship behavior, including which sex initiated searching and courtship. We conducted our experiments in the laboratory because this species lives mainly in black waters, where visibility is restricted.

The courtship behavior of most South American turtles is unknown (Pritchard and Trebbau 1984; Molina 1996b), and there are no published descriptions of the courtship behavior of turtles in the genus Podocnemis. In a genus where there are often two, sometimes three sympatric species, there may be an intricate sequence of behavior involved in courtship to prevent hybridization, much like those in Graptemys or the Trachemys group (Gibbons and Lovich 1990; Vogt 1993). Further, studies of courtship behavior provide useful information for management of these or other closely related species of management and conservation concern (Andrade 2009). Even though, such studies are lacking in Brazil and most biodiversity and management plans for wildlife include recommendations 
for studying reproductive biology (Brasil 1998; Capobianco 2001).

\section{Methods}

We collected 20 female and 39 male adult P. erythrocephala using trammel nets, between February and July 2006 in the Cumicuri River, municipality of Barcelos, Amazonas, Brazil $\left(00^{\circ} 41^{\prime} \mathrm{S}, 63^{\circ} 12^{\prime} \mathrm{W}\right)$. The turtles were transported to the Instituto Nacional de Pesquisas da Amazônia in Manaus (Brazil), and maintained individually in plastic aquaria. Turtles were sexed visually by external sexual characteristics. Males have a distinctive bright red pattern on the head. Females are larger than males and males have longer, thicker tails. All turtles were individually marked by notching their marginal scutes (Cagle 1939). We conducted 150 observation sessions of 3-6 h per day (total of $450 \mathrm{~h}$ ), using the "all occurrence sampling" method (Altman 1974), during 100 days. We identified the conducts and followed the names given in the literature of behavioral items already described. New items were named according to the context in which they were observed.

Observers stayed at about three meters from the aquarium, in order to be as unobtrusive as possible. One female and three males were acclimated to the experimental aquarium for one hour before the start of each session, and after each session they were returned to their individual tanks to allow a better adaptation of pairs to the observers. Turtles were observed horizontally and after some of observatory session, we spent time taking pictures of the main categories which were the base for sketches and understanding of the phases.

Each female was used in a maximum of eight sessions, and each of these sessions was with 3 different males. To avoid the problem of pseudoreplication we randomly drew numbers of the three males to be tested in a session with a female from the stock of males she was not tested with before. Thus each female was tested only once with each male. We always changed the water between experimental sessions.

Behaviors patterns were described and grouped into three phases (after Carpenter and Ferguson 1977; Auffenberg 1977, 1978; Molina 1996a). The primary phase involves the male searching for the female; the second phase involves mounting attempts of the male and the response of the female; the third phase involves copulation, which includes copulation attempts and movements after copulation. We recorded all male approaches, and subsequent behavior, whether they led to copulation or not. We also continued to observe the turtles to note whether males continued to approach females. Female receptivity was defined as a female that responded to the initial approach of a male by ceasing movement and allowing courtship to proceed.

\section{Results}

Courtship sequences

We observed three phases of courtship in P. erythrocephala: searching, precopulation, and copulation. All descriptions of the three phases are presented in Table 1.

In the 150 sessions, 37 males actively courted females $(95 \%)$ and two inactively $(5 \%)$. The mean number of courtship events by each male was 2.2 (range $1-7 ; \mathrm{SD}=1.8$ ). Nine females were sexually active $(45 \%)$, and 11 were inactive $(65 \%)$. The mean number of courtship events per female was 2.4 (range $1-7 ; \mathrm{SD}=1.9$ ).

The total time of the interactions between pairs that culminated in copulation was 10 to $20 \mathrm{~min}$ (mean=12.1). After a period of 2 to 30 min (mean=8.5), males again approached females or never approached again. Although all males eventually approached females, in $36 \%$ of the trials there was no interaction (females were unreceptive and moved away). When males initially approached females, they initially accepted the male's advances (14\%), rejected the male passively by swimming rapidly away $(38 \%)$, or rejected the male aggressively by biting (48\%). In $86 \%$ of the cases where males were rejected, they approached the female again, and $51 \%$ of the time, they were ultimately successful.

These data indicate that females were initially receptive only $14 \%$ of the time, but most males $(86 \%)$ continued their pursuit, and they were successful $51 \%$ of the time. In this species, the larger females can both avoid the male by moving away initially or during any subsequent pursuit, or they can be aggressive. However, even males initially rejected by females, biting them aggressively, continued their pursuit.

\section{Discussion}

Courtship: behavioral cues to receptivity

Courtship patterns in this study were classified in a similar manner as those described for many species in the families Kinosternidae (Sexton 1960; Mahmoud 1967; Lardie 1975; Bels and Crama 1994) and Chelidae (Molina 1996a, b; Richard 1999). Stereotyped behavioral patterns are initiated by males searching for females but have different sequential patterns, depending on the receptivity of the females. The precopulation behavioral patterns vary between species. 
Table 1 Detailed description of the courtship behavior pattern

\begin{tabular}{llll}
\hline & Phase & Action & Subphase \\
\hline Courtship & Searching & Recognition of opposite sex \& acceptance of male by female & $\begin{array}{l}\text { Olfaction } \\
\text { Approaching } \\
\text { Precopulation }\end{array}$ \\
Copulation & $\begin{array}{c}\text { Series of behavioral patterns that precede copulation, characterized by movements that might lead } \\
\text { to copulation. Precopulation can be initiated with or without a male's pursuit } \\
\text { Female demonstrates receptivity to male, their tails come in contact, their cloacas are juxtaposed, } \\
\text { \& male's penis is inserted into cloaca of female }\end{array}$ & $\begin{array}{c}\text { Coitus } \\
\text { After } \\
\text { copulation }\end{array}$ \\
\hline
\end{tabular}

To date, three basic behavioral cues have been associated with courtship behavior in turtles: visual, tactile, and olfaction (Carpenter 1980). However, recently Giles (2005) found that freshwater turtles vocalize under water. The visual displays males make to attract a female's attention are often complemented by tactile behavior, such as biting and rubbing of the carapaces. The female that rejects a male can respond visually with a repertoire of aggressive behavioral patterns.

Tactile behavior, principally biting, is a common component of courtship behavior of many animals (Krebs and Davis 1993), and we also observed biting in all phases of the courtship behavior in $P$. erythrocephala. Biting behavior as a part of courtship has been described in a number of species of turtles Kinosternon scorpioides (Sexton 1960), Chrysemys scripta (Davis and Jackson 1973), Podocnemis vogli (Ramo 1982), Sternotherus minor (Bels and Crama 1994), and Phrynops geoffroanus (Molina 1996a, b). Possibly this biting behavior is sexually stimulating to females or threatens them into submission.

Scent may be used by males to discover the reproductive state of females. This is suggested by the male's touching their nostrils to females' cloaca (Stacey et al. 1986). This touching was used throughout courtship in the present study. However, since all species of turtles have long-term sperm storage (Gist and Jones 1989), it is unlikely that female turtles exude some type of cloacal odor signifying receptivity since they should be receptive throughout the year. Thus, we suggest that cloacal touching may aid identification of the sex of the turtle (or even the species).

We noted that on some occasions, the male did not appear to use olfactory behavior and went directly to the female to attempt to copulate. Direct or immediate mounting behavior has been described for other species, including P. geoffroanus (Molina 1996a, b) and Kinosternon flavescens flavescens (Lardie 1975). In Acanthochelys pallidipectoris, smelling behavior is rapid (Horne 1993), and it does not exist in the courtship described for Platemys platycephala (Harding 1983). This behavior suggests several hypotheses concerning the reproductive biology of turtles: (a) males can detect the odor of a conspecific female at a distance and do not need to put their nostrils close to her body to sense her smell; (b) the decision of the male can be based solely on visual characteristics of the female; (c) both sexes could be emitting another type of signal such as sound, which up to now has not been recognized in courtship studies of aquatic turtles but has been shown to be a characteristic of courtship in many species of tortoises (Sacchi et al. 2003); or (d) a combination of the above.

Relative to the first hypothesis, it is likely that males are able to detect the pheromones of females at a distance by using olfactory receptors specifically developed for this behavior, given that some males approached females and copulated without cloacal contact with their nostrils. There are no published studies involving experiments to discover the minimum distances that turtles need to detect odors. However, Vogt (1979) suggested that in Chrysemys picta, it was necessary for the male to almost have his nostrils in contact with the female before he reacted to her as being a receptive conspecific female.

Relative to the second hypothesis, the experiments we conducted show that the carapace and the head of the females are larger than those of the male, so it is possible that males can distinguish females visually by morphological differences in size, as has been suggested for other species of turtles (Moll and Legler 1971; Legler 1990). Females can also be recognized by the dark brown color of the head, as opposed to the contrasting bright red markings of males.

The third hypothesis suggests that both sexes are able to produce and detect sounds (Sacchi et al. 2003). Giles (2005) recorded one type of sound produced underwater during the courtship of Chelodina oblonga, but other studies are needed to examine the generality of this finding.

Considering the above, the actual mechanism that males use to identify conspecific females is unknown. Vogt (1979) suggested that male aquatic turtles recognize conspecific females using both visual and olfactory cues. Pheromones have not been identified in freshwater turtles, but could be present and give both sexual, as well as species-specific cues. These pheromones could be dispersed widely in the water, and individuals would 
need to be in close proximity to the turtle for detection of these species-specific or sexually identifying odors. In tortoises (Geochelone), Auffenberg (1965) demonstrated that males needed to come in contact with the cloacal region of an individual for recognition of conspecific females.

\section{Female receptivity and male pursuit}

In the present study, P. erythrocephala males continued to court females if they were not aggressively rejected; they did not need the stimulus of an entirely receptive female to continue courting her. Several times in the course of capturing $P$. erythrocephala with trammel nets in the Rio Negro Basin, Vogt (unpublished) captured up to five males, usually two to three, within $1 \mathrm{~m}$ of a female. This suggests that the males were actively courting her. Vogt (1979) also observed this behavior in nature with C. picta: two to five males courting the same female.

The behavior of males pursuing or chasing females in groups has been documented in a number of species of freshwater turtles, including Clemmys guttata and Trachemys gaigeae and Phrynops hilarii (Legler 1955; Mahmoud 1967; Ernst 1970; Stuart and Jennifer 1998; Richard 1999). Perhaps the pursuing of females stimulates the males to induce them into the next sequences of courtship leading to copulation. This pursuit behavior could lead to successful copulation (Mahmoud 1967; Davis and Jackson 1970). During our experiments with P. erythrocephala, we observed 18 copulations; 15 were the results of males chasing females. There are no other published reports of the frequency of copulations resulting from males chasing females for any other species of turtle.

During chases, the males maintained the neck outstretched, as was described for Pelomedusa subrufa (Ernst 1980). On some occasions, the males discontinued the chase for some unknown reason. This was also noted for P. hilarii (Richard 1999) and P. geoffroanus (Molina 1996a, b).

The precopulatory phase occurs when the male is able to maintain himself on top of the female, resting his forelimbs on her carapace. This behavior is similar to that found in other species of turtles (Sexton 1960; Mahmoud 1967; Lardie 1975). During the precopulation phase, the male maintains the neck outstretched, batting her neck, biting her, or simulating trying to bite the head of the female. This behavior pattern is common in other species of Chelidae, $P$. geoffroanus, and P. hilarii (Molina 1996a, b; Richard 1999). A P. erythrocephala female in the precopulation phase can passively accept the male (indicating her receptivity) or attempt to throw him off, as has been observed in Kinosternon and Phrynops (Mahmoud 1967; Molina 1996a, b).
The duration of the copulatory act in P. erythrocephala lasted about $20 \mathrm{~s}$. The duration of copulation is highly variable among turtles. For example in Trachemys scripta elegans, the duration was $13 \mathrm{~min}$ (Davis and Jackson 1970), and in Trachemys dorbignyi, the duration was $2 \mathrm{~min}$ (Molina 1995). In K. flavescens flavescens, Kinosternon subrubbrum, Sternotherus odoratus, and Sternotherus carinatus, Mahmoud (1967) mentioned that the time spent from the initiation of courtship to copulation lasted from $10 \mathrm{~min}$ to $3 \mathrm{~h}$ for the first species and $5 \mathrm{~min}$ to $2 \mathrm{~h}$ for the other three species. In this study, the total time $P$. erythrocephala spent from the initiation of courtship until the termination of copulation lasted a mean of $12 \mathrm{~min}$, range $10-20 \mathrm{~min}$, which is rapid in comparison to other species studied.

In conclusion, female P. erythrocephala in this study demonstrated receptivity by allowing courtship and copulation, or they rejected the male immediately (either passively or actively). However, if males continued to pursue females, the females often allowed the pursuit and eventually participated in courtship and copulations. This suggests that receptivity is partly a continuum from partial receptivity (which needs to be encouraged with further pursuit) to full receptivity where females will immediately participate in courtship and copulation. These experiments were conducted in a laboratory setting where females could not permanently escape the male by swimming away. In nature, females could continue swimming until the smaller male gives up. Whether this happens or whether females routinely elicit pursuit as part of full courtship can only be tested in much larger enclosures with sufficient space for escape, or in nature (where the black waters of their native habitat make this difficult). In addition, allowing males to pursue them may allow females to gauge the strength of male sexual strength, providing another aspect to female mate choice and evaluation of male quality. Future experiments should involve the use of hydrophones to document the possibility that they are vocalizing underwater during courtship.

Acknowledgments This project was funded by Fundação de Amparo a Pesquisa do Estado do Amazonas grant 2003-916 to R. C. Vogt. Instituto Nacional do Meio Ambiente e dos Recursos Naturais Renováveis issued all of the appropriate permits. All protocols for the treatment of animals in captivity published by AAAS were followed. Rio Negro Lodge Foundation and the Phil Marsteller family are thanked for their hospitality and logistic support. Camila was funded by a Conselho Nacional de Desenvolvimento Científico e Tecnológico scholarship during her masters, and JB was funded by P30ES005022 and DE-FC01-06EW07053 and New Jersey Audubon Society.

Open Access This article is distributed under the terms of the Creative Commons Attribution Noncommercial License which permits any noncommercial use, distribution, and reproduction in any medium, provided the original author(s) and source are credited. 


\section{References}

Alcock J (1993) Animal behavior: an evolutionary approach. Sinauer Associates, Sunderland

Altman J (1974) Observational study of behavior: sampling methods. Anim Behav 49:227-267

Anderson M (1994) Sexual selection. Princeton University Press, Princeton

Andrade PCM (2009) Criação e Manejo de Quelônios no Amazonas (Projeto diagnostico da criação de animais silvestres no estado do Amazonas). PRIOVARZEA-AQUABIO, Manaus

Auffenberg W (1965) Sex and species discrimination in two sympatric South American tortoises. Copeia 1965:335-342. doi:10.2307/ 1440797

Auffenberg W (1977) Display behavior in tortoises. Am Zool 17:241250

Auffenberg W (1978) Courtship and breeding behavior in Geochelone radiata (Testudines: Testudinidae). Herpetologica 34(3):277-287

Bels VL, Crama YJM (1994) Quantitative analysis of the courtship and mating behavior in the in the Loggerhead Musk Turtle Stenotherus minor (Reptilia: Kinosternidae) with comments on courtship behavior in turtles. Copeia 17(3):676-684. doi: $10.2307 / 1447183$

Berry JF, Shine R (1980) Sexual size dimorphism and sexual selection in turtles (order Testudines). Oecologia 44(2):185-191. doi:10.1007/BF00572678

Brasil (1998) Relatório nacional para a condução sobre a diversidade biológica. Ministério do Meio Ambiente, dos Recursos Hídricos e da Amazônia legal, Brasília, D.F.

Cagle FR (1939) A system of marking turtles for future identification. Copeia (3):170-173. doi:10.2307/1436818

Capobianco JPR (2001) Biodiversidade na Amazônia Brasileira: avaliação e ações prioritárias para a conservação, uso sustentável e repartição de benefícios, MMA, Instituto Socioambiental, Brasília

Carpenter CC (1980) An ethological approach to reproductive success in reptiles. In: Murphy JB, Collins JT (eds) Reproductive biology and diseases of captive reptiles. Society for the Study of Amphbians and Reptiles, Kansas, pp 33-48

Carpenter CC, Ferguson GW (1977) Variation and evolution of stereotyped behavior in reptiles. In: Gans C, Tinkle DW (eds) Biology of the reptilia: ecology and behavior. Academic, London, pp 335-554

Davis JD, Jackson CG Jr (1970) Copulatory behavior in the RedEared Turtle, Pseudemys scripta elegans (WIED). Herpetologica 26(2):238-240

Davis JD, Jackson CG Jr (1973) Notes on the courtship of a captive male Chrysemys scripta taylori. Herpetologica 29(1):62-64

Ernst CH (1970) Reproduction in Clemmys guttata. Herpetologica 26 (2):228-232

Ernst CH (1980) Courtship of the African helmeted turtle (Pelomedusa subrufa). Britsh J Herpetol 6:141-142

Gibbons JW, Lovich JE (1990) Sexual dimorphism in turtles with emphasis on the slider turtle (Trachemys scripta). Herpetol Monogr 4:1-29. doi:10.2307/1466966

Giles J (2005) The underwater acoustic repertorie of the long-necked, freshwater turtle Chelodina oblonga. PHD School of Environmental Science, Murdoch University, Perth, p 224
Gist DH, Jones JM (1989) Sperm storage within the oviduct of turtles. J Morphol 199:379-384

Harding JH (1983) Platemys platycephala (Twistneck Turtle). Reproduction. Herpetol Rev 14(1):22

Horne B (1993) Courtship behavior and oviposition of captive Acanthochelys pallidipectoris Freiberg. SSAR Herpetol Rev 24 (1):25

Krebs JR, Davis NB (1993) An Introduction to behavioral ecology. Blackwell Science Press, Cambridge

Lardie RL (1975) Courtship and mating behavior in the yellow mud turtle, Kinosternon flavescens flavescens. J Herpetol 9(2):223227. doi: $10.2307 / 1563041$

Legler JM (1955) Observations on the sexual behavior of captive turtles. Lloydia 18(2):95-99

Legler JM (1990) The genus Pseudemys in mesoamerica: taxonomy, distribution, and origins. In: Gibbons JW (ed) Life history and ecology of the slider turtle. Smithsonian Institution Press, Washington, D. C., pp 82-105

Mahmoud IY (1967) Courtship behavior and sexual maturity in four species of Kinosternid turtles. Copeia (2):314-319. doi:10.2307/ 1442119

Molina FB (1995) Observações sobre a biologia e o comportamento reprodutivo de Trachemys dorbignyi (Duméril \& Bibron, 1835) em cativeiro (Reptilia, Testudines, Emydidae). PHD apresentada pelo Instituto de Biociências da Universidade de São Paulo, São Paulo, Brasil, p 307

Molina FB (1996a) Biologia e comportamento reprodutivo de quelônios. A Etol 14:211-221

Molina FB (1996b) Mating behavior of captive Geoffroys's sideneck turtle, Phrynops geoffroanus (Testudines: Chelidae). Herpetol Nat Hist 4:155-160

Moll EO, Legler JM (1971) The life history of a neotropical slider turtle, Pseudemys scripta (Schoeoff), in Panama. Nat Hist Mus Los Angeles 11:1-102

Pritchard PCH, Trebbau P (1984) The turtles of Venezuela. Society for the Study of Amphibians and Reptiles, Ithaca

Ramo C (1982) Biologia del Galapago (Podocnemis vogli, Muller, 1935) em el hato el frio. Llanos de Apure (Venezuela). Donãna-A Vert 9:1-73

Richard E (1999) Tortugas de las Regiones Aridas de Argentina. Literature of Latin America (L.O.L.A.), Buenos Aires

Sacchi R, Galeotti P, Fasola M et al (2003) Vocalization and courtship intensity correlate with mounting success in marginated tortoise Testudo marginata. Behav Ecol Sociobiol 55:95-102. doi:10.1007/s00265-003-0685-1

Sexton OJ (1960) Notas sobre la reproducción de una tortuga venezolana, la Kinosternon scorpioides. M Cienc Nat La Salle 20(57):189-197

Stacey NE, Kyle AL, Liley NR (1986) Fish reproductive pheromone. In Chemical signals in vertebrates. Plenum New York 4:117-134

Stuart JN, Jennifer BM (1998) Trachemys gaigeae (Big Bend Slider). Courtship behavior. Herp Rev 29(4):235-236

Vogt RC (1979) Spring aggregating behavior of painted turtles, Chrysemys picta (Reptilia, Testudines, Testudinidae). J Herpetol 13(3):363-338. doi:10.2307/1563336

Vogt RC (1993) Systematics of the false map turtle (Graptemys pseudogeographica) complex: Reptilia, Testudines, Emydidae). Ann Carnegie Mus 62(1):1-46 